Original Research

\title{
Characteristics of Sleep Quality of Nursing Students in Bali During Pandemic Covid-19
}

\author{
Putu Intan Daryaswanti ${ }^{1 *}$, Ni Made Diah Pusparini Pendet ${ }^{1}$, \& Ni Putu Eka \\ Febianingsih $^{1}$ \\ ${ }^{1}$ STIKES Kesdam IX/Udayana, Denpasar, Indonesia
}

\begin{tabular}{|c|c|}
\hline Article Info & Abstract \\
\hline $\begin{array}{l}\text { Article history: } \\
\text { Received: } \\
25 \text { July } 2021 \\
\text { Accepted: } \\
29 \text { July } 2021\end{array}$ & $\begin{array}{l}\text { Introduction: Corona Virus Disease-19 (COVID-19) has spread to } 34 \\
\text { provinces in Indonesia. Indonesia first confirmed the case of COVID-19 in } \\
\text { March 2020. The outbreak of the COVID-19 pandemic has made the } \\
\text { teaching and learning process shifted to distance teaching. This activity- } \\
\text { limiting measure in response to curbing the spread of COVID-19 has } \\
\text { caused an unprecedented change in human behavior around the world. }\end{array}$ \\
\hline $\begin{array}{l}\text { Keywords: } \\
\text { sleep quality, } \\
\text { adolescence, Covid- } \\
\text { 19, student of } \\
\text { nursing }\end{array}$ & $\begin{array}{l}\text { process that is highly dependent on the environment and social and varies } \\
\text { greatly with stress levels. This study aimed to know the characteristics of } \\
\text { sleep quality of nursing students during pandemic Covid-19 in Bali. } \\
\text { Methods: This study is a descriptive study using univariate analysis. The } \\
\text { population in this study is approximately 1,500 nursing students. Sampling } \\
\text { technique used in this research is purposive sampling with } 422 \text { sample. } \\
\text { Data collection tools in the form of questionnaires that are used is a sleep } \\
\text { quality questionnaire from the Pittsburg Sleep Quality Index (PSQI). } \\
\text { Results: The results show that most of the nursing students' age ranged } \\
\text { from } 15-25(94.1 \%) \text {, female ( } 79.1 \% \text { ) and currently undergoing Bachelor of } \\
\text { Nursing education (68\%) and students of Nursing in Bali mostly have poor } \\
\text { sleep quality ( } 97.4 \%) \text {. } \\
\text { Conclusion: Students of Nursing reported to have poor sleep quality over } \\
\text { the last month. }\end{array}$ \\
\hline
\end{tabular}

*Corresponding Author:

e-mail: intan.daryaswanti@gmail.com

This work is licensed under a Creative Commons Attribution 4.0 International License. 


\section{INTRODUCTION}

Corona Virus Disease-19 (COVID-19) has spread to 34 provinces in Indonesia. Indonesia first confirmed the case of COVID19 in March 2020, where there were 2 people who contracted the corona virus. The outbreak of the COVID-19 pandemic has made the teaching and learning process shifted to distance teaching. This activity-limiting measure in response to curbing the spread of COVID-19 has caused an unprecedented change in human behavior around the world.

One of the changes in human behavior is sleep. Sleep is a physiological process that is highly dependent on the environment and social and varies greatly with stress levels. Conceivably, the environmental and social changes caused by the pandemic have been shown to affect sleep time and duration in several recent studies across different populations [1]. In a pandemic, fear increases anxiety, stress levels and insomnia in otherwise healthy individuals [2]. For most non-essential workers in Indonesia, particularly in Bali, travel restrictions result in a requirement to work from home, and students are tutored at home by teachers/lecturers via virtual. Thus, travel is unnecessary for most workers and students, and there may be increased flexibility for scheduled work and study assignments throughout the day; Clearly, there are potential implications for sleep timing and quality that may arise from a radical rearrangement of the previous routine schedule [3].

Most teenagers in various countries around the world get less sleep. Lack of sleep has a negative impact on mental and physical health in youth. Interventions to prolong adolescent sleep duration have had limited success [4]. Sleep disturbances are a common health problem among adolescents and young adults and there is a belief that these groups of students do not have enough sleep [5]. Since the outbreak, people's sleep quality has deteriorated (38.3\%), difficulty in initiating sleep (29.8\%) and short sleep duration (29.1\%) and insomnia (29.9\%)[6].

The results of interviews with 10 nursing students found that 5 people had difficulty starting to sleep, 2 people experienced short sleep duration, 2 people experienced sleep efficiency disorders and 1 person said they didn't have sleep disorders. The prevalence of sleep disorders in general population has been estimated at 15\%-35\% [7]. Student groups usually have a solid activity. In the morning, most students have to get up early to attend lectures that last until noon or evening. Students can have difficulty sleeping because they do assignments that require students to stay up late and even early in the morning. The higher the level of fatigue experienced by students, the worse the quality of their sleep. The fatigue that a person gets from work that exceeds one's ability will cause a load of fatigue that will interfere with his sleep process. If the sleep process is disturbed, the expected quality of sleep will not be achieved. This study aimed to know the characteristics of sleep quality of nursing students during pandemic Covid-19 in Bali.

\section{METHODS}

This study is a descriptive study using univariate analysis. The population in this study is approximately 1,500 nursing 
students. Sampling technique used in this research is purposive sampling. Calculation of sample size based on proportion estimation population. The minimum sample size needed is 384 people, but to overcome the possibility of lack of response rate than the minimum number of samples is added by $10 \%$, so that the sample size to be taken is 422 people.

Data collection tools in the form of questionnaires distributed using google form. Questionnaire used is a sleep quality questionnaire from the Pittsburg Sleep Quality Index (PSQI). The inclusion criteria in this study were students who were registered as nursing students in Bali. This instrument consists of sleep duration, sleep disturbances, daily dysfunction, sleep efficiency, complaints sleep and use of sleeping pills. Consisting of 9 question items, the total score is between 0-

21. Over score A low score indicates that the patient has impaired sleep quality, while a higher score indicates a patient with optimal sleep quality. Validity and reliability test of the instrument PSQI has been tested in Cunha's study with a validity value of 0.89 and a reliability of 0.88 [8]. This research has passed the ethical test at the Research Ethics Commission of the Faculty of Medicine, Udayana University, Sanglah Central General Hospital Denpasar with number 1502/UN 14.2.2.VII.14/LT/2021 date of 28th May 2021.

\section{RESULTS}

Table 1 shows that most of the nursing students' age ranged from 15-25 (94.1\%), female (79.1\%) and currently undergoing Bachelor of Nursing education (68\%). Table 2 shows nursing students in Bali mostly have poor sleep quality (97.4\%).

\section{Table 1}

Characteristics student of nursing in Bali

\begin{tabular}{|c|c|c|}
\hline Characteristic & $\mathbf{n}$ & $\%$ \\
\hline \multicolumn{3}{|l|}{ Age (Years) } \\
\hline $15-25$ & 400 & 94.1 \\
\hline $26-35$ & 16 & 3.8 \\
\hline $36-45$ & 8 & 1.9 \\
\hline $46-55$ & 1 & 0.2 \\
\hline \multicolumn{3}{|l|}{ Gender } \\
\hline Man & 89 & 20.9 \\
\hline Woman & 336 & 79.1 \\
\hline \multicolumn{3}{|l|}{ Education } \\
\hline Magister Nursing & 1 & 0.2 \\
\hline Ners & 20 & 40.7 \\
\hline Bachelor of Nursing & 289 & 68 \\
\hline Diploma III Nursing & 24 & 6.0 \\
\hline Total & 425 & 100 \\
\hline
\end{tabular}


Table 2

Sleep of Quality Student of Nursing in Bali

\begin{tabular}{lccc}
\hline & Sleep of Quality & n & \% \\
\hline Good & & 11 & 2.6 \\
Poor & Total & 414 & 97.4 \\
\hline & & $\mathbf{4 2 5}$ & $\mathbf{1 0 0}$ \\
\hline
\end{tabular}

\section{DISCUSSION}

Following the outbreak of Covid-19, Indonesia chose to implement Community Activity Restrictions as preventive measures to curb the highly contagious virus, including online education. A recent study conducted during the Covid-19 pandemic on students around the world also observed dramatic changes in health issues including sleep quality. Adolescence is a time of biological and social change that profoundly affects sleep and risk taking. Although good sleep is important at all developmental stages, sleep may have a consequential effect on cognitive and affective function during adolescence, especially in the developmental phase when sleep quality is poor [9].

The results of the study from age, most of the students were in the age of 15-25 (94.1\%) according to research [10] which showed $43.1 \%$ was 22 years old. Among the participants $(n=425), 79.1 \%$ were female and the rests were male (20.9\%). More than $60 \%$ of the participants enrolled in bachelor of Nursing. About $97.4 \%$ of the university students reported to have poor sleep quality over the last month. Student groups usually have a solid activity. In the morning, most students have to start to take part in the ongoing lectures until noon or sick. Students may have difficulty sleeping due to doing assignments which require students to stay up late and even early in the morning. The higher the level of fatigue experienced by students, the quality of sleep is getting worse. The fatigue that getting someone from work that exceeds one's abilities, will cause fatigue that will interfere with the process of sleep. when the sleep process is disturbed, then the expected quality of sleep will not be achieved.

The Covid-19 pandemic has been reported to affect mental health. Therefore, quarantine conditions at home clinically have the meaning of making people suffer from insomnia. In particular, people who slept well before the pandemic experienced a greater reduction in sleep quality than before the pandemic [1]. In addition, some empirical studies document a higher prevalence of poor sleep quality and sleep disturbances during the current pandemic [11]. In the world of education, there is a change in the learning system that was previously done offline or face to face to be online. In online learning, the tasks given are certainly more than offline. Most of the students in this study experienced sleep disturbances during the pandemic. Students are mostly restless with high academic expectations, successful academic completion and future academic prospects as 
well as a professional career [12], on the other hand, students may feel psychologically depressed because of the home environment, competitive or jealous colleagues, being away from family or fear of contracting the Covid19 disease. Studies show that most of the common mental health problems among college students are sleep disturbances due to high academic and mental stress [13].

\section{CONCLUSION}

The results of the study from age, most of the students were in the age of 15-25 (94.1\%). Among the participants ( $n=425), 79.1 \%$ were female and the rests were male (20.9\%). More than $60 \%$ of the participants enrolled in Bachelor of Nursing. About $97.4 \%$ of the university students reported to have poor sleep quality over the last month.

\section{REFERENCES}

[1] D. Kocevska, T. F. Blanken, and E. J. W. Van Someren, "Sleep quality during the COVID-19 pandemic: not one size fi ts all," Sleep Med., vol. 76, no. December 2019, pp. 2019-2021, 2020.

[2] A. Neves, J. Pipa, E. Santa, T. Santiago, P. Viana, and M. Drummond, "Sleep quality in times of Covid-19 pandemic Josu e," Sleep Med., vol. 74, pp. 81-85, 2020.

[3] S. Raman and A. N. Coogan, "Effects of societal-level COVID-19 mitigation measures on the timing and quality of sleep in Ireland *," Sleep Med., no. xxxx, 2021.

[4] R. Gruber, S. Saha, G. Somerville, J. Boursier, and M. S. Wise, "The impact of COVID-19 related school shutdown on sleep in adolescents: a natural experiment," Sleep Med., vol. 76, pp. 3335, 2020.

[5] H. L. Orzech K.M., Salafsky D.B., "The state of sleep among college student at a large public university," J. Am. Coll. Heal., vol. 59, no. 7, pp. 612-619, 2011.

[6] B. Y. Yu, W. Yeung, J. C. Lam, S. C. Yuen, S. Ching, V. C. Chung, K. Chung, P. Hong, F. Y. Ho, and J. Y. Ho, "Prevalence of sleep disturbances during COVID-19 outbreak in an urban Chinese population : a crosssectional study," Sleep Med., vol. 74, pp. 18-24, 2020.

[7] J. Priya, J. Singh, and S. Kumari, "Study of the factors associated with poor sleep among medical students," Indian J. Basic Appl. Med. Res., vol. 6, no. 3, pp. 422-429, 2017.

[8] D. J. Buysse, C. F. Reynolds, T. H. Monk, S. R. Berman, and D. J. Kupfer, "The Pittsburgh Sleep Quality Index: A New Instrument Psychiatric Practice and Research," Psychiatry Res., vol. 28, pp. 193-219, 1989.

[9] I. M. Colrain and F. C. Baker, "Changes in Sleep as a Function of Adolescent Development," Neuropsychol Rev, vol. 21, no. 1, pp. 5-21, 2011.

[10] D. A. Martfandika and P. P. Rahayu, "Kualitas tidur mahasiswa keperawatan dalam menyusun skripsi di universitas ‘aisyiyah yogyakarta,' 2018.

[11] F. Beck, D. Leger, L. Freesard, P. PerettiWatel, P. Verger, and G. Coconel, "Covid19 health crisis and lockdown associated with high level of sleep complaints and 
hipnotic uptake at the population level," Sleep Res, vol. 30, no. 1, 2021.

[12] R. Beiter, R. Nash, D. Rhoades, M. Linscomb, M. Clarahan, and S. Sammut, "The prevalence and correlates of depression, anxiety, and stress in a sample of college students," J. Affect. Disord., vol. 173, pp. 90-96, 2015.
[13] P. Zou, X. Wang, L. Sun, K. Liu, G. Hou, W. Yang, C. Liu, H. Yang, N. Zhou, G. Zhang, X. Ling, J. Liu, J. Cao, L. Ao, and Q. Chen, "Poorer Sleep Quality Correlated with Mental Health Problems in College Students: A Longitudinal Observational Study among 686 males," J. Psychosom. Res., vol. 136, 2020. 